\title{
Nutrient limitation of Philippine seagrasses (Cape Bolinao, NW Philippines): in situ experimental evidence
}

\author{
Nona S. R. Agawin ${ }^{1, *}$, Carlos M. Duarte ${ }^{2}$, Miguel D. Fortes ${ }^{1}$ \\ ${ }^{1}$ Marine Science Institute, CS, University of The Philippines, Diliman, Quezon City 1101, The Philippines \\ ${ }^{2}$ Centre d'Estudis Avancats de Blanes, CSIC, Cami de Santa Bàrbara s/n, E-17300 Blanes, Girona, Spain
}

\begin{abstract}
Nutrient limitation of Enhalus acoroides, Thalassia hemprichii and Cymodocea rotundata in 2 mixed seagrass beds (Silaqui and Lucero) in Cape Bolinao, NW Philippines was investigated through a 4 mo in situ nutrient addition experiment. Leaf growth of $T$ hemprichii and E. acoroides significantly increased by 40 to $100 \%$ and $160 \%$, respectively, following fertilization. Leaf biomass of the 3 species also increased significantly by 60 to $240 \%$ following nutrient additions. The increased growth and biomass with fertilization was supported by enhanced photosynthetic activity, consequently by higher chlorophyll and nutrient concentrations in the photosynthetic tissues. These results demonstrated nutrient limitation of seagrass growth and photosynthetic performance at the 2 sites in Cape Bolinao. The nature and extent of nutrient limitation, however, varied between sites and among species. $T$ hemprichil and $E$. acoroides appeared to be mainly $P$ deficient and $N$ deficient, respectively (from significant increases in tissue $\mathrm{P}$ and $\mathrm{N}$ concentration following fertilization, respectively). The deficiency was moderate ( $26 \%$ of requirement) for $T$ hemprichii but substantial for E. acoroides $(54 \%$ of requirement). Moreover, $\mathrm{N}$ and $\mathrm{P}$ deficiency was greater in Lucero than in Silaqui, consistent with the higher ambient nutrient concentration in the porewater and sediment nutrient and organic matter content in Silaqui. These results emphasize the importance of local differences in the factors controlling nutrient losses and gains in seagrass meadows and, more importantly, the importance of identifying the species-specific traits that generate the interspecific plasticity of nutrient status.
\end{abstract}

KEY WORDS: Tropical seagrasses · Nutrient limitation

\section{INTRODUCTION}

Seagrass beds can support highly productive coastal ecosystems whenever nutrient and light availability are adequate (McRoy 1974, Hillman et al. 1989). In temperate regions, often characterized by turbid waters, light is considered to be the most important factor limiting seagrass growth (Giesen et al. 1990). However, in most tropical seas, which are usually characterized by clear waters and high incoming irradiance throughout the year, seagrass growth is often limited by the availability of nutrients (Powell et al. 1989, Short et al. 1990, Duarte 1995).

- Present address: Centre d'Estudis Avancats de Blanes, CSIC, Cami de Santa Bàrbara s/n, E-17300 Blanes, Girona, Spain. E-mail:agawin@azathoth.ceab.es
The importance of nutrient limitation as a constraint to seagrass growth is still a subject of controversy (Hillman et al. 1989, Duarte 1990, Erftemeijer 1993), partly because direct tests are still few in both temperate (Orth 1977. Pérez et al. 1991, Murray et al. 1992) and tropical (Powell et al. 1989, Short et al. 1990, Bulthuis et al. 1992, Duarte 1995) meadows. Nutrient limitation of SE Asian meadows has only been examined at a single location (South Sulawesi, Indonesia; Erftemeijer et al. 1994), for which no evidence of nutrient limitation of the growth of Thalassia hemprichii and Enhalus acoroides was found. Apparently, nutrient supply met seagrass demands in the area studied, where plants grew over both terrigenous and carbonate sediments (Erftemeijer et al. 1994).

There is, therefore, a need to expand our knowledge of the occurrence of nutrient-limited growth of SE 
Asian seagrasses to confirm whether they differ or not from those growing in tropical areas elsewhere, which show nutrient-limited growth (Powell et al. 1989, Short et al. 1990, Bulthuis et al. 1992, Duarte 1995). Here we contribute to this issue by providing an experimental test of the role of nutrient supply in controlling the growth, biomass, and photosynthesis of a set of mixed (Cymodocea rotundata, Thalassia hemprichii, and Enhalus acoroides) seagrass stands growing in Cape Bolinao (Pangasinan, NW Philippines).

The mixed seagrass meadows growing in Cape Bolinao support relatively high biomass and productivity (Vermaat et al. 1995a). This suggests a high nutrient demand, which could render these seagrass meadows particularly prone to suffering nutrient limitation. Unpublished data on leaf nutrient concentrations for these meadows (Agawin et al. unpubl. results) indicate that these seagrasses are slightly deficient in both nitrogen ( $N$ ) and phosphorus (P). The leaf $N$ concentration of Enhalus acoroides was $1.61 \%$ DW (dry weight), and the leaf $\mathrm{P}$ concentration of Cymodocea rotundata and Thalassia hemprichii was 0.17 and $0.19 \%$ DW, respectively, slightly below the median values for seagrasses $(1.8 \%$ DW for nitrogen and $0.20 \%$ DW for phosphorus; Duarte 1990). Hence, comparison of nutrient levels in the seagrasses in Cape Bolinao with median values for seagrass stands (Duarte 1990) suggests seagrasses in Cape Bolinao to be nutrient deficient.

The extent of seagrass nutrient limitation in Cape Bolinao is likely to vary as a result of local variability in factors that affect nutrient availability. A 14 mo study of 2 seagrass meadows in Cape Bolinao has demonstrated contrasting productivities, with lower productivity in Lucero than in Silaqui (Vermaat et al. 1995b). Lucero is characterized by faster water currents and exposure to waves (Agawin 1995, Vermaat et al. 1995 b) which may reduce nutrient availability, thereby enhancing nutrient losses through exportation and preventing nutrient accumulation through sediment erosion. As a result, sediments are coarser and sandier in Lucero than in Silaqui (Balunos 1994, Agawin 1995), suggesting contrasting nutrient availability in sediments as a possible cause for the difference in seagrass productivity between Lucero and Silaqui meadows, provided that light availability was similar at both sites.

Here we tested the extent of nutrient limitation of the dominant seagrasses (i.e. Cymodocea rotundata, Thalassia hemprichil, and Enhalus acoroides) in 2 contrasting meadows in Cape Bolinao. We did so by examining their response to a 4 mo period in which nutrients were added to sediments. Seagrass response was assessed through the examination of growth, biomass, tissue nutrient content, leaf chlorophyll content, and photo- synthetic parameters. In addition to examining the response to fertilization, we also compared the nutrient status of the seagrasses at the 2 sites by comparing estimates of nutrient incorporation and requirements for seagrasses at the 2 sites on the basis of data on leaf tissue nutrient concentration (Pedersen \& Borum 1993, Erftemeijer \& Middelburg 1995).

\section{MATERIALS AND METHODS}

Study area. The study was conducted from $13 \mathrm{Sep}$ tember 1994 to 18 January 1995 at the period of growth depression of Cape Bolinao seagrasses (Vermaat et al. 1995b). Nutrient addition experiments were conducted at 2 sites on a shallow, extensive back-reef lagoon, both supporting lush mixed seagrass beds. Silaqui $\left(16^{\circ} 27.03^{\prime} \mathrm{N}, 119^{\circ} 55.35^{\prime} \mathrm{E}\right)$ is a protected subtidal station on coral sand between Silaqui Island and the larger Santiago Island, and Lucero $\left(16^{\circ} 24.72^{\prime} \mathrm{N}\right.$, $119^{\circ} 54.42^{\prime} \mathrm{E}$ ) is an exposed subtidal station in Santiago Island located along the path of tidal flushing in and out of the back-reef lagoon. Average water depth is $0.8 \mathrm{~m}$ at Silaqui and $0.6 \mathrm{~m}$ at Lucero. Maximum semi-diurnal tidal range is $0.75 \mathrm{~m}$. The Silaqui site was located $20 \mathrm{~m}$ from the shoreline while Lucero was located $100 \mathrm{~m}$ away from shore. Average $( \pm \mathrm{SE})$ incident irradiance (PAR) at midday (September to January) was $1313 \pm 200 \mu \mathrm{M} \mathrm{m} \mathrm{m}^{-2} \mathrm{~s}^{-1}$ in Lucero and $1115 \pm 169 \mu \mathrm{M} \mathrm{m}^{-2} \mathrm{~s}^{-1}$ in Silaqui (Rivera unpubl.).

The mixed seagrass beds in Silaqui and Lucero are composed of Enhalus acoroides (L. f.) Royle, Thalassia hemprichii (Ehrenb.) Aschers., Cymodocea rotundata Ehrenb. \& Hempr. ex Aschers., Cymodocea serrulata (R. Br.) Aschers. \& Magnus, Halodule uninervis (Forssk.) Aschers., Halophila ovalis (R. Br.) Hook f., and Syringodium isoetifolium (Aschers.) Dandy. $T$. hemprichii quantitatively dominates the meadows both numerically and in annual productivity, and along with E. acoroides, which occurs as scattered clumps, dominates the biomass (Vermaat et al. 1995a). Total biomass (excluding roots) of meadows in Cape Bolinao reaches up to $624 \mathrm{~g} \mathrm{DW} \mathrm{m}^{-2}$ and annual productivity (roots excluded) up to $2140 \mathrm{~g} \mathrm{DW} \mathrm{m}^{-2} \mathrm{yr}^{-1}$ (Vermaat et al. 1995a).

Experimental design. Six experimental plots $(0.3 \times$ $0.3 \mathrm{~m}$ each) were established in the area with mixed Thalassia hemprichii and Cymodocea rotundata shoots at both sites. Three plots were enriched with complete fertilizer and 3 were used as controls, which were subjected to the same sediment disturbance as the enriched plots but with no fertilizer. To assess the effect of experimental sediment disturbance alone on the plants, another 3 plots were left undisturbed (undisturbed controls) at 1 site (Lucero). Experimental 
sediment disturbance, however, did not significantly (ANOVA, p > 0.05) affect shoot elongation, total shoot length, leaf width, biomass of leaves, stems, roots and rhizomes, and total biomass (aboveground + belowground), nor the proportion of biomass allocated to non-photosynthetic and photosynthetic parts. The treatments and the controls were assigned to the plots in a randomized complete block design, using a table of random numbers. Distance between treatments within a block was $1 \mathrm{~m}$, and between blocks was $2 \mathrm{~m}$.

Enhalus acoroides occurs as scattered clumps in the area, rather than as a homogeneous meadow (Vermaat et al. 1995a). Individual E. acoroides clumps were, therefore, used as the experimental units, with 2 nearby clumps forming a block. Six $E$. acoroides clumps $(0.3 \times 0.3 \mathrm{~m})$ were, therefore, selected, as 3 sets of 2 neighbouring (about $1 \mathrm{~m}$ ) clumps positioned about $2 \mathrm{~m}$ away from each other, conforming to the randomized complete block design.

Fertilization procedure. Nutrient additions were conducted using a commercial complete slow-release fertilizer $[8 \%$ Total Nitrogen $10.4 \%$ organic, $3 \%$ nitrate/nitrite, $4.6 \%$ ammonium), $8 \% \mathrm{P}_{2} \mathrm{O}_{5}, 10 \% \mathrm{~K}_{2} \mathrm{O}$, and $12 \%$ organic matter], which has proven effective in promoting seagrass growth in past experiments (Pérez et al. 1991, Alcoverro et al. 1995, Duarte 1995). Nutrient additions were applied by pushing 5 fertilizer sticks ( 6 to $7 \mathrm{~cm}$ long, cut into 2 pieces each) $10 \mathrm{~cm}$ into the sediment at each treatment plot in an even manner using a grid. Each nutrient addition to each experimental plot supplied $5.3 \mathrm{~g} \mathrm{~N}$ and $2.3 \mathrm{~g} \mathrm{P}$, equal to a loading of $59 \mathrm{~g} \mathrm{~N} \mathrm{~m}^{-2}$ and $26 \mathrm{~g} \mathrm{P} \mathrm{m}^{-2}$. This loading exceeded the upper range of annual nutrient requirement for seagrass growth, estimated to be 6.6 to $50 \mathrm{~g} \mathrm{~N} \mathrm{~m}^{-2}$ (Hemminga et al. 1991) and 0.7 to $5.5 \mathrm{~g}$ $\mathrm{P} \mathrm{m} \mathrm{m}^{-2}$ (calculated from the average seagrass tissue molar N:P of 20; Erftemeijer 1993), and thus ensured that none of the nutrients were limiting in the experimental fertilized plot. The application of the fertilizer was repeated every 15 d over the 4 mo duration of the experiment.

Monitoring of physico-chemical characteristics. Sediment porewater was sampled using a modification of the method of Bulthuis et al. (1992). Samples (100 to $125 \mathrm{ml}$ ) of porewater were withdrawn from $10 \mathrm{~cm}$ below the sediment surface at each plot with $20 \mathrm{ml}$ syringes perforated at the base. Similar samples were collected at each plot $10 \mathrm{~cm}$ above the sediment surface. The samples were placed on ice and transported to the laboratory, where they were immediately filtered through Whatman GF/C filters, and frozen for subsequent analyzes. Porewater samples were collected monthly while water column samples were obtained every 2 mo. Samples were taken just before the fertilizations. Inorganic nutrient concentration
$\left(\mathrm{NO}_{3}^{-1}+\mathrm{NO}_{2}^{-1}, \mathrm{PO}_{4}^{-3}\right)$ in the water samples was determined using an autoanalyzer, and $\mathrm{NH}_{4}{ }^{+}$concentration was analyzed spectrophotometrically following the methods described by Strickland \& Parsons (1972). Water temperature was monitored monthly using a min-max thermometer deployed for $24 \mathrm{~h}$ at each site. Salinity was also monitored monthly using a refractometer.

At the end of the fertilization period, all plants were harvested from each plot using a metal corer of $20 \mathrm{~cm}$ diameter. Sediment samples for organic matter (OM) determination were oven-dried at $80^{\circ} \mathrm{C}$ until constant weight, and $O M$ was subsequently determined from weight loss of a $10 \mathrm{~g} \mathrm{DW}$ sample combusted at $550^{\circ} \mathrm{C}$ for $6 \mathrm{~h}$. Using the remaining fresh sediment material, the $\% \mathrm{~N}$ of the sediment's dry weight, and available $\mathrm{P}$ (soluble reactive phosphate + organically bound forms) in the sediment samples, were analyzed at The Bureau of Soils and Water Management (Quezon City, The Philippines) using the Kjeldal and Vanado-molybdate methods, respectively.

Seagrass response. The number of shoots of each species per plot was counted at monthly intervals beginning at the start of the nutrient additions. The number of rhizome apices was also counted after harvesting at the end of the fertilization period. Response in terms of density was determined with Thalassia hemprichii because a 4 mo fertilization does not allow for changes in shoot density of the slow-growing Enhalus acoroides (Vermaat et al. 1995b). The density of Cymodocea rotundata, which is very patchy in the area, was also monitored. The patchiness of this species, however, induced great variance in shoot density and leaf biomass among plots and resulted in very low power to determine the response in these descriptors.

At least 15 shoots of each species per plot were randomly chosen to estimate leaf growth using the method of Zieman (1974). All leaves in a shoot were marked just above the meristem by punching 2 parallel holes with a hypodermic needle, and tagging the shoots with colored plastic markers (cf. Pérez et al. 1991). The marked shoots were harvested after a period scaled to the leaf growth of each species (Vermaat et al. 1995b), the distance the holes travelled in every leaf was measured and the new (intact) leaves were measured to calculate growth. The sum of leaf lengths in a shoot and leaf width was also measured. Leaf growth of Thalassia hemprichii was assessed monthly with marking intervals of $15 \mathrm{~d}$. Leaf growth of Enhalus acoroides was assessed using 30 d intervals, since this species has a slower leaf turnover (Vermaat et al. 1995a), and the low density of shoots prevented harvest of marked shoots at shorter intervals. No efforts were made to estimate growth of Cymodocea rotundata. 
At the end of the fertilization period, all plants were harvested in each plot using a $20 \mathrm{~cm}$ diameter corer to include the roots and rhizomes in the samples (Vermaat et al. 1995a). Adhering sediments were washed off the roots and rhizomes, after collection of samples for sediment analyzes. Plants were sorted by species, cleaned and separated into leaves and roots-rhizomes. The leaves, and vertical and horizontal rhizomes with the associated roots, were weighed after drying in an oven $\left(80^{\circ} \mathrm{C}\right)$ for $48 \mathrm{~h}$.

Photosynthesis-irradiance $(P-I)$ curves were obtained once at the middle of the experiment. The $P-I$ experiment was conducted using the flow-through respirometry device described in Montebon \& Yap (1995a). The device can accommodate 4 chambers (one of which serves as the blank) placed in a water bath with controlled stirring, and light (using screens). The seawater in each of the 4 chambers is supplied from an aerated tank with flow regulated at $30 \mathrm{ml} \mathrm{min}^{-1}$ and chamber outlets are connected to a multi-way cock which enables quasisimultaneous dissolved oxygen readings with a single oxygen microelectrode (Montebon \& Yap 1995b). Temperature in the water bath containing the chambers was controlled with a heat trap consisting of running water between 2 sheets of glass below the light source.

Approximately $0.50 \mathrm{~g}$ wet weight of the second youngest leaf of each seagrass species present in a treatment within each block was enclosed in a chamber, and inserted (or weaved) at the base. The leaves were exposed to increasing irradiances of $0,120,225$, 435,820 and $2100 \mu \mathrm{E} \mathrm{m} \mathrm{m}^{-2} \mathrm{~s}^{-1}$ (measured within the chambers using a LI-COR 193SA sensor), removing black screens inserted between the light source and the chambers. Three chambers were used for the leaf samples and the fourth one served as a blank. The samples were incubated at each irradiance level until a uniform slope was reached (typically $10 \mathrm{~min}$ ), and oxygen concentrations were recorded on a strip chart recorder, the blank chamber first, then the other 3 in succession. The leaves were flushed with new water for 5 min in between light treatments.

Extraction of chlorophyll $a$ and $b$ from the seagrass leaves was done by grinding about 0.1 to $0.3 \mathrm{~g}$ wet weight of second youngest leaf with a mortar and pestle in $96 \%$ ethanol. After extraction in the dark for $12 \mathrm{~h}$, the suspensions were centrifuged at $1000 \times \mathrm{g}$ for $10 \mathrm{~min}$ and absorbance at 665 and $649 \mathrm{~nm}$ measured using a double beam Hitachi model 200-20 spectrophotometer. Chlorophyll $a$ and $b$ concentrations were determined using the formula of Wintermans \& De Mots (1965).

The second youngest leaf of each seagrass species and a sample of randomly chosen horizontal rhizomes were pooled for each species in each plot and dried at $80^{\circ} \mathrm{C}$ to a constant weight $(24$ to $48 \mathrm{~h})$. The dried samples were powderized using an electric grinder and analyzed at The International Institute for Hydraulic and Environmental Engineering, Delft (The Netherlands) for nitrogen and phosphorus concentrations using a Tecator 3400 autoanalyzer after digestion with $\mathrm{H}_{2} \mathrm{SO}_{4} / \mathrm{Se} /$ salicylic acid and $\mathrm{H}_{2} \mathrm{O}_{2}$.

Data analyses. Multiway Analysis of Variance (ANOVA) was used to describe, for each species, the variability of the response variables (except density) as a function of site, blocks nested within sites, treatment, time (whenever a response variable was measured more than once), and interaction effects. Comparisons of treatments were conducted using Tukey's HighestSignificant-Difference (HSD) means test (Sokal \& Rohlf 1981). Data were log transformed if the condition of homogeneity of variances was not met. Variability in density values was analyzed using repeated measures analysis of variance (ANOVAR). Photosynthesis-irradiance curves were analyzed statistically with a repeated measure design test (MANOVAR or ANOVAR; Potvin et al. 1990), and a hyperbolic tangent model was fitted to describe them. This procedure yielded estimates of maximum photosynthetic rate $\left(P_{\max }\right)$, respiration rate $(R), I_{C}$, the irradiance at which respiration equals photosynthesis (light compensation points, $I_{C}$ ). and $\alpha$, the slope of the curve at low light levels (photosynthetic efficiency, $\alpha$ ).

The nutritional status of the plants was also assessed on the basis of calculations of nutrient deficiency, based on the balance betweer nitrogen and phosphorus requirements and incorporation. Nutrient requirements were calculated as the product between the nutrient-sufficient seagrass leaf production of fertilized plants and the nutrient concentration of the control plants. Plants can absorb nutrients in excess of requirements (i.e luxury uptake), so that calculations based on nutrient concentrations of control plants are more conservative. Nutrient incorporation was calculated as the product of leaf production of unfertilized plants and the concentration of fully grown unfertilized leaves (leaf number 2 in this study). Nutrient deficiency can then be approximated as the difference between requirements and incorporation (Pedersen \& Borum 1993, Alcoverro et al. 1995).

\section{RESULTS}

The waters at Lucero and Silaqui had similar properties (average salinity $34.2 \pm 0.5$ and $34.0 \pm 0.1 \mathrm{ppt}$, respectively; average minimum and maximum water temperature $26.4 \pm 1.7$ and $34.3 \pm 0.7^{\circ} \mathrm{C}$ at Lucero, and $26.1 \pm 2.8$ and $34.6 \pm 1.3^{\circ} \mathrm{C}$ at Silaqui\}. Total available $P$, percent total $N$, and organic matter concentrations of sediments at Silaqui were higher than at 
Table 1 Mean ( \pm SE) nutrient concentrations in waters and sediments in fertilized and control plots in Silaqui and Lucero $(\mathrm{N}=6)$

\begin{tabular}{|c|c|c|c|c|}
\hline & \multicolumn{2}{|c|}{ Silaqui } & \multicolumn{2}{|c|}{ Lucero } \\
\hline & Fertilized & Control & Fertilized & Control \\
\hline \multicolumn{5}{|l|}{ Sediment } \\
\hline Available P (ppm) & $146.0(9.9)$ & $22.0(2.4)$ & $78.8(10.1)$ & $14.6(0.8)$ \\
\hline$\%$ total N & $0.14(0.01)$ & $0.13(0.02)$ & $0.09\{0.01\}$ & $0.08(0.00)$ \\
\hline$\%$ organic matter & $7.4(0.1)$ & $7.1(0.4)$ & $6.3(0.2)$ & $6.0(0.1)$ \\
\hline \multicolumn{5}{|l|}{ Porewater } \\
\hline \multicolumn{5}{|l|}{$\mathrm{PO}_{4}(\mu \mathrm{M})$} \\
\hline 13 September & $2.0(0.6)$ & $2.7(1.1)$ & $0.5(0.1)$ & $0.7(0.2)$ \\
\hline 12 October & $101.8(74.5)$ & $1.1(0.4)$ & $77.2(37.9)$ & $0.5(0.2)$ \\
\hline 15 November & $39.9(13.8)$ & $0.2(0.0)$ & $28.1(12.4)$ & $1.4(1.2)$ \\
\hline 13 December & $19.3(6.8)$ & $0.2(0.0)$ & $28.3(17.5)$ & $0.2(0.0)$ \\
\hline 18 January & $62.7(11.8)$ & $0.3(0)$ & $9.3(5.0)$ & $0.2(0.0)$ \\
\hline \multicolumn{5}{|l|}{$\mathrm{NH}_{4}(\mu \mathrm{M})$} \\
\hline 13 September & $23.2(5.4)$ & $16.4(5.7)$ & $19.8(5.0)$ & $21.6(6.4)$ \\
\hline 12 October & $182.5(107.6)$ & $9.6(1.6)$ & $54.4(7.6)$ & $21.7(6.7)$ \\
\hline 15 November & $152.4(33.9)$ & $4.8(1.0)$ & $78.6[40.0\}$ & $3.8(0.6)$ \\
\hline 13 December & $22.8(4.1)$ & $8.3(5.1)$ & $18.2(3.3)$ & $1.9(0.5)$ \\
\hline 18 January & $87.6(21.9)$ & $2.2(0.3)$ & $9.5(2.5)$ & $3.1(0.8)$ \\
\hline \multicolumn{5}{|l|}{$\mathrm{NO}_{3}+\mathrm{NO}_{2}(\mu \mathrm{M})$} \\
\hline 13 September & $2.1(0.6)$ & $1.7(0.3)$ & $1.5(0.4)$ & $1.8(0.4)$ \\
\hline 12 October & $3.8(0.9)$ & $2.2(0.5)$ & $1.5(0.2)$ & $3.1(1.3)$ \\
\hline 15 November & $1.3(0.4)$ & $1.8(1.0)$ & $1.2(0.4)$ & $0.7(0.3)$ \\
\hline 13 December & $2.4(0.5)$ & $0.5(0.1)$ & $1.8(0.5)$ & $0.6(0.1)$ \\
\hline 18 January & $1.7(0.3)$ & $0.7(0.1)$ & $1.6(0.3)$ & $1.1(0.3)$ \\
\hline \multicolumn{5}{|l|}{ Water column } \\
\hline \multicolumn{5}{|l|}{$\mathrm{PO}_{4}(\mu \mathrm{M})$} \\
\hline 13 September & $0.2(0.0)$ & $0.2(0.0)$ & $0.2(0.0)$ & $0.2(0.0)$ \\
\hline 15 November & $0.2(0.0)$ & $0.2(0.0)$ & $0.1(0.0)$ & $0.1(0.0)$ \\
\hline 18 January & $0.2(0.0)$ & $0.1(0.0)$ & $0.1(0.0)$ & $0.1(0.0)$ \\
\hline \multicolumn{5}{|l|}{$\mathrm{NH}_{4}(\mu \mathrm{M})$} \\
\hline 13 September & $1.5(0.1)$ & $1.6(0.1)$ & $1.8(0.1)$ & $1.5(0.2)$ \\
\hline 15 November & $2.2(0.3)$ & $1.9(0.2)$ & $1.8(0.1)$ & $1.7(0.2)$ \\
\hline 18 January & $1.8(0.3)$ & $1.8(0.2)$ & $2.0(0.4)$ & $1.8(0.3)$ \\
\hline \multicolumn{5}{|l|}{$\mathrm{NO}_{3}+\mathrm{NO}_{2}(\mu \mathrm{M})$} \\
\hline 13 September & $0.6(0.0)$ & $0.6(0.1)$ & $0.5(0.0)$ & $0.4(0.0)$ \\
\hline 15 November & $0.6(0.2)$ & $0.4(0.1)$ & $0.6(0.3)$ & $0.6(0.5)$ \\
\hline 18 January & $0.7(0.0)$ & $0.8(0.1)$ & $0.7(0.1)$ & $0.6(0.0)$ \\
\hline
\end{tabular}

Lucero (Table 1). Sediment porewater nutrient concentrations were higher at Silaqui than at Lucero, whereas water column nutrient concentrations were similar at both sites (Table 1 ). As a result of nutrient additions, phosphate and ammonium concentrations in sediment porewaters increased greatly relative to those in control plots. In contrast, nitrate + nitrite concentrations did not vary between fertilized and control plots, both in the water column and sediment porewaters, at either site (Table 1). Available phosphorus concentrations increased several fold in responses to nutrient additions. However, both the percent total nitrogen and organic matter did not differ significantly between fertilized and unfertilized plots at either sites. Hence, nutrient additions greatly increased phosphate and ammonium concentrations at both sites, without affecting their concentration in the water column.
The $\mathrm{P}$ concentration of both leaves and rhizomes of Thalassia hemprichil significantly (ANOVA, $p<0.05$ ) increased in response to nutrient additions (Fig. 1). Fertilization also significantly increased (ANOVA, $\mathrm{p}<0.05$ ) the $\mathrm{N}$ concentration of the rhizomes of T. hemprichii at both sites (Fig. 1). The nitrogen concentration of Enhalus acoroides leaves, but not the $\mathrm{P}$ concentration, increased significantly (ANOVA, $p<0.01$ ) in response to nutrient additions at both sites (Fig 1) Insufficient replicate leaf samples of Cymodocea rotundata prevented statistical comparison of the response of nutrient concentrations to nutrient additions, but nitrogen and phosphorus contents tended to increase at both sites (Fig. 1). The concentrations of chlorophyll a and $b$ in leaves of all 3 species tended to increase in response to fertilization (Fig, 1), but this increase was statistically significant (ANOVA, $p<0.05$ ) only for C. rotundata (Fig. 1).

Nutrient additions significantly influenced the overall $P-I$ response curves of each of the 3 species (MANOVAR, light level $\times$ treatment, $p<$ 0.01; Fig. 2), but not at both sites. The efficiency and maximum rate of photosynthesis of Cymodocea rotundata increased in Lucero, whereas the respiration rate and light compensation point declined in plants growing in fertilized plots (Table 2). No significant response of $P-I$ curves to nutrient additions was found for $C$. rotundata in Silaqui (MANOVAR, light level $\times$ treatment, $p>0.05$ ). Similar trends in the response of $P-I$ parameters to nutrient additions were observed for Thalassia hemprichii in Silaqui (Fig. 2, Table 2), although these changes were smaller than those observed for $C$. rotundata in Lucero. The $P$ - $I$ curve of $T$. hemprichii plants growing in fertilized plots at Lucero did not differ from that of control plants (MANOVAR, light level $\times$ treatment, $\mathrm{p}>$ 0.05). The P-I curve of Enhalus acoroides leaves from plants growing at Silaqui also showed an increase in maximum rate of photosynthesis, a decrease in respiration rate and light compensation irradiance in response to nutrient additions (Fig. 2, Table 2). As in T. hemprichii, the $P$-I curve of $E$. acoroides plants growing at Lucero did not show any significant difference in response to nutrient additions (MANOVAR, light level $\times$ treatment, $p>0.05$ ). 

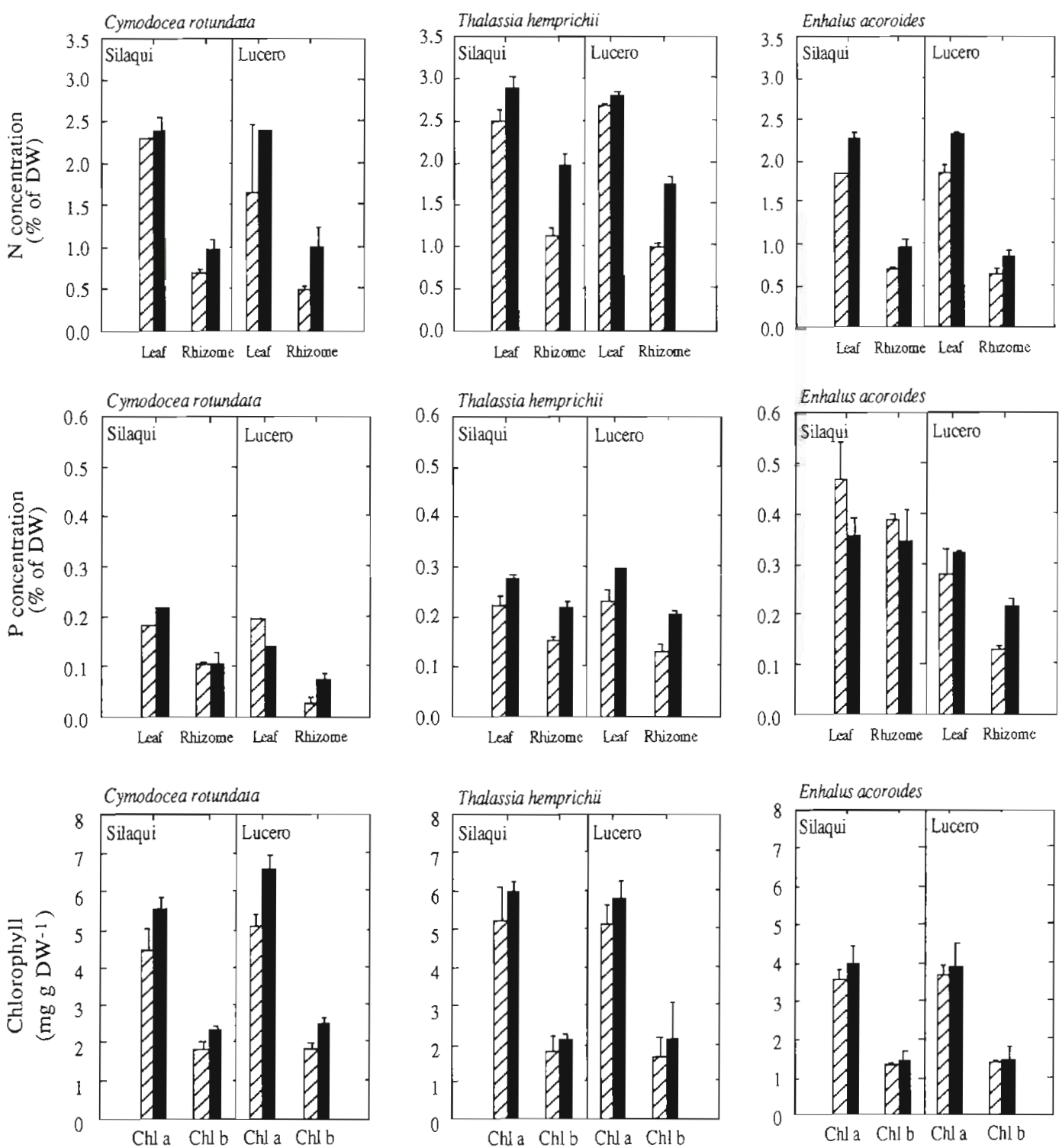

Fig. 1. Cymodocea rotundata, Thalassia hemprichii and Enhalus acoroides. Nitrogen and phosphorus concentrations in Ieaves (leaf no. 2) and rhizomes, and leaf chlorophyll $a$ and $b$ concentrations (mean $\pm S E$ ) in control (hatched bars) and fertilized (solid bars) plots

Nutrient additions significantly increased the density of Thalassia hemprichii at both sites (ANOVAR, $p<0.001$ ). The extent of this effect increased with time (ANOVAR, treatment $\times$ month, $p<0.001$ ) becoming significant as of November (Tukey's means test, p < 0.05 ), about 2 mo after the start of fertilization (Fig 3). The density of rhizome apices also increased significantly in response to fertilization at both sites (ANOVA, $p<0.05$ ), increasing by 102 and $82 \%$ in Silaqui and Lucero, respectively (Agawin 1995). The changes in shoot density were closely correlated with the increase in the density of rhizome apices $(r=0.88$, $p<0.05$ ), clearly demonstrating that nutrient additions enhanced rhizome branching and growth, which resulted, in turn, in increased shoot density (cf. Pérez et al. 1991). Density of Cymodocea rotundata also increased in response to nutrient additions at both sites, although it was more evident in Silaqui, where density increased as of November, than in Lucero (Fig. 4).

Fertilization significantly increased growth of Thalassia hemprichii shoots (ANOVA, $p<0.001$ ), this effect varying with time and between sites (ANOVA, treatment $\times$ site $\times$ month, $p<0.05$ ). Shoot elongation significantly increased in response to fertilization $1 \mathrm{mo}$ and 2 mo after the onset of fertilization in Silaqui and Lucero, respectively (Tukey's means test, $p<0.05$ ). In Silaqui, leaf growth increased by 48 and $36 \%$ over controls in November and December, respectively, while 


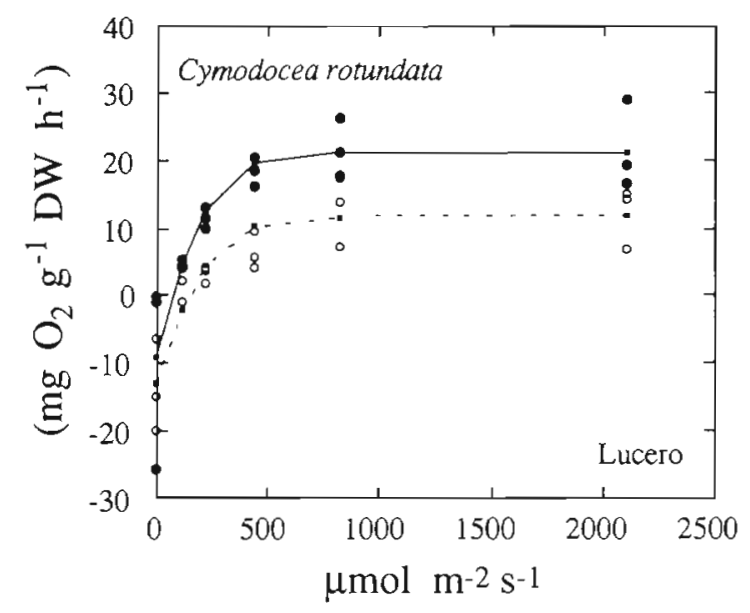

Fig. 2. Photosynthesis-irradiance response curves of seagrass leaves following in situ nutrient enrichment (only curves where response were significant shown). Broken and solid lines represent the curves for control (o) and fertilized ( $\bullet$ plants, respectively

in Lucero it increased 62 and $95 \%$ over that in the controls in November and December, respectively (Fig. 3). In December, all treatments (but it was more evident in the controls) showed the seasonal growth depression at both sites. Fertilization also stimulated growth of Enhalus acoroides significantly (ANOVA, $\mathrm{p}<0.05$ ) by a similar extent (about $160 \%$ ) at both sites (Fig. 5). As a

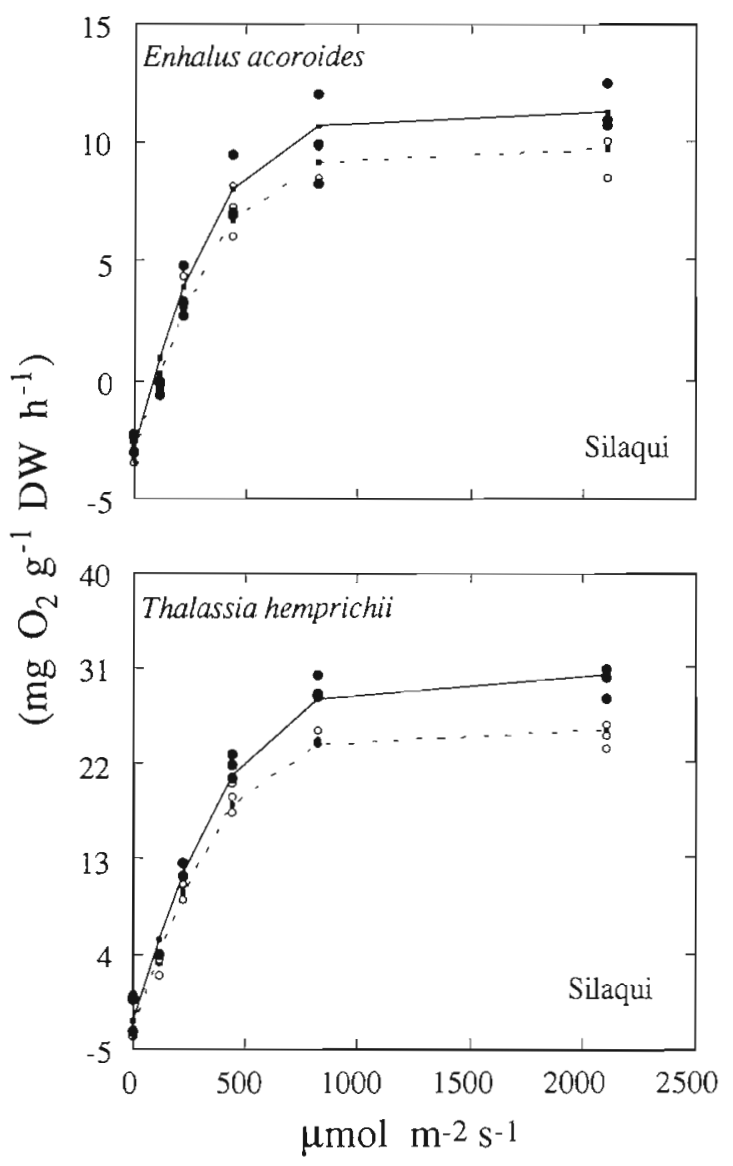

result of the increase in leaf growth, the size of both $T$. hemprichii and $E$. acoroides shoots increased significantly at both sites (ANOVA, p < 0.001) in response to nutrient enrichment, the difference in shoot size between fertilized and control plots increasing significantly with time for $T$. hemprichii (ANOVA, treatment $\times$ month, $p<0.001$ ) (Agawin 1995). As a result, fertilization significantly increased (ANOVA, $\mathrm{p}<0.01$ ) the leaf biomass of $T$. hemprichii by 60 and $115 \%$ over the controls in Silaqui and Lucero, respectively (Fig. 3), as well as that of $E$. acoroides, which increased significantly only at Lucero (by about $240 \%$; Fig. 5). Fertilization also increased the leaf biomass of Cymodocea rotundata in Silaqui by $90 \%$ over that in the control whereas no trend of increase in Lucero was observed; however, this may be due to the considerable variance in leaf biomass among plots in Lucero (Fig. 4). The effects of nutrient addition were much smaller, and not statistically significant, on the biomass of vertical rhizomes and the total biomass (aboveground + belowground) of 

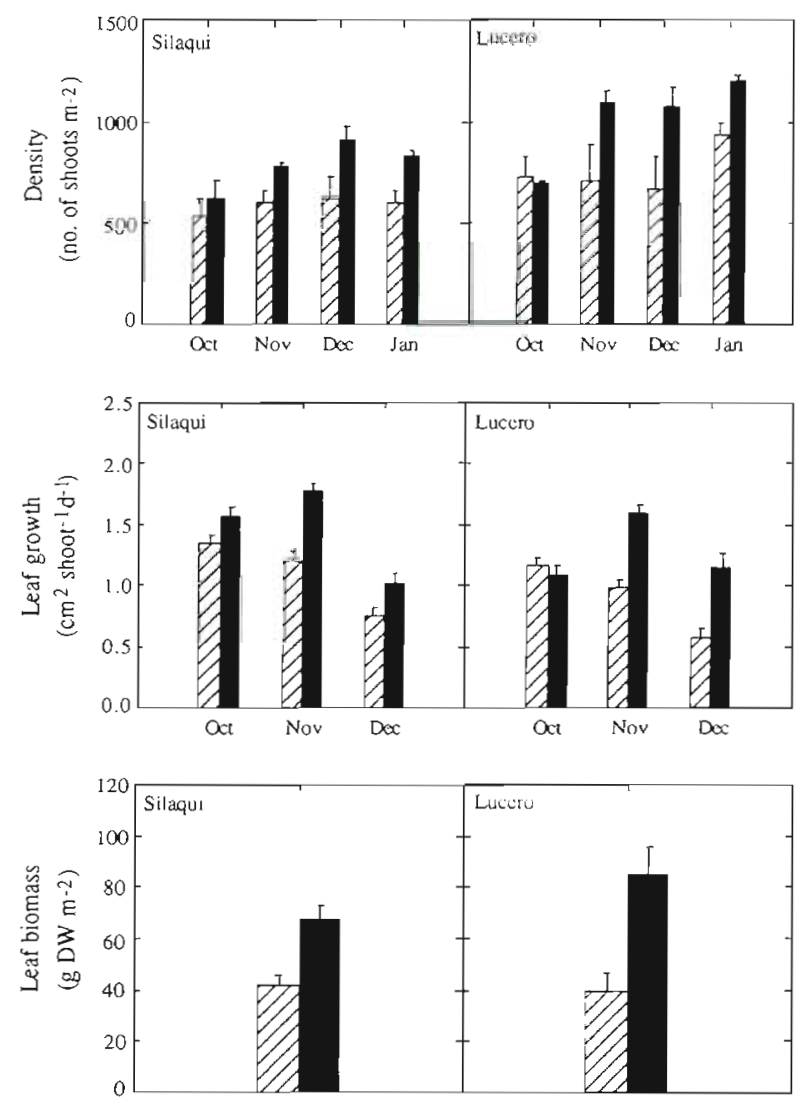

Fig. 3. Thalassia hemprichil. Shoot density, leaf growth and leaf biomass (mean $\pm \mathrm{SE}$ ) in control (hatched bars) and fertilized (solid bars) plots
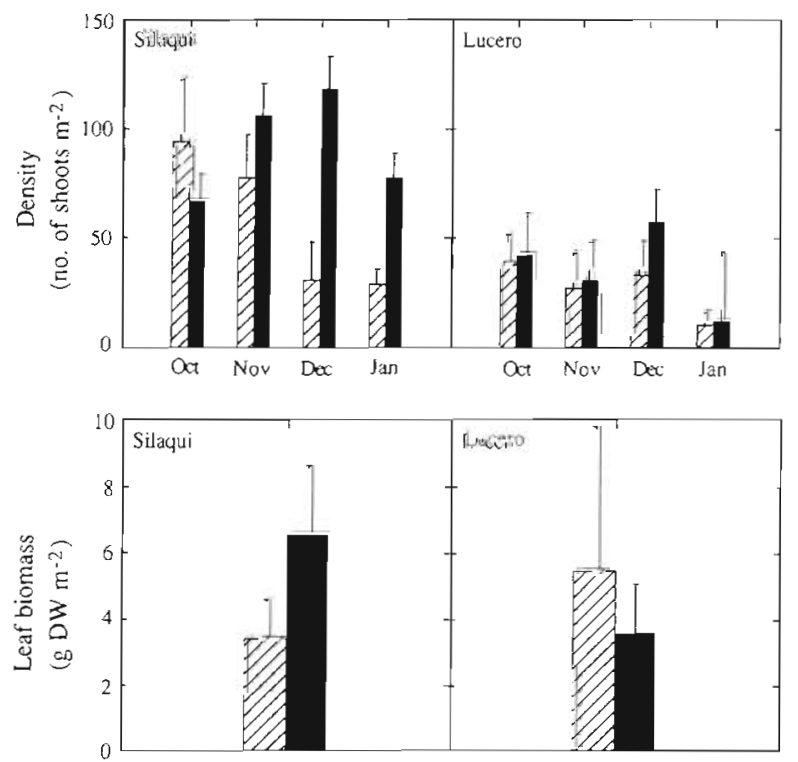

Fig. 4. Cymodocea rotundata. Shoot density and leaf biomass (mean $\pm \mathrm{SE}$ ) in control (hatched bars) and fertilized (solıd bars) plots
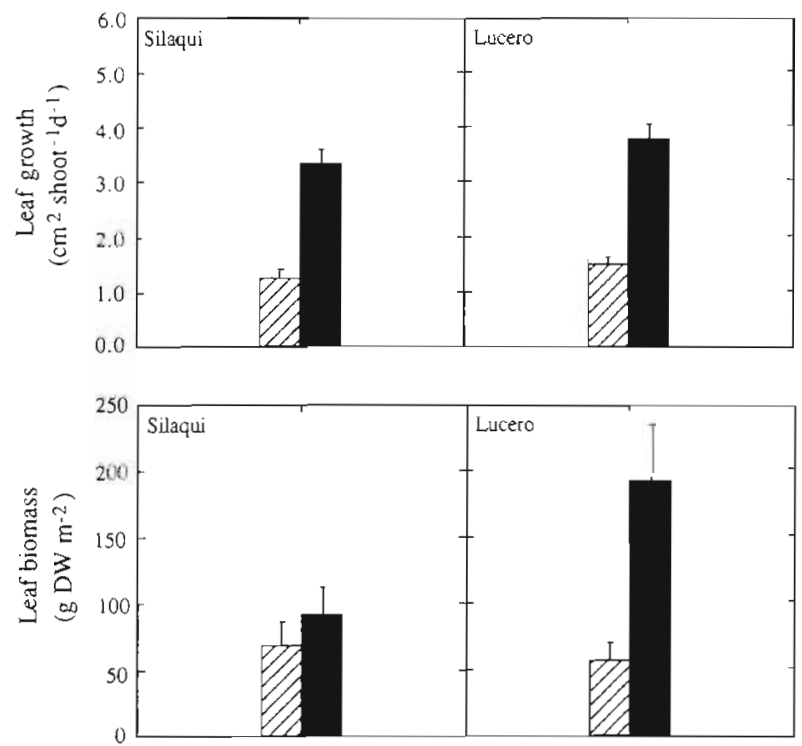

Fig. 5. Enhalus acoroides. Leaf growth and leaf biomass of (mean $\pm \mathrm{SE}$ ) in control (hatched bars) and fertilized (solid bars) plots

T. hemprichii (Agawin 1995), as expected from the slow turnover of the shoots and rhizome compartments (cf. Vermaat et al. 1995a). The belowground biomass (rhizome + roots) of $T$. hemprichii, however, declined in response to nutrient additions (Agawin 1995)

The nutrients required by each species were quite similar among sites, whereas there were important differences in the extent of nutrient deficiency between sites and species. Both Thalassia hemprichil and Enhalus acoroides experienced $\mathrm{N}$ and $\mathrm{P}$ deficiency (Table 3). $\mathrm{N}$ and $\mathrm{P}$ deficiency was moderate (about $26 \%$ of requirements) for $T$. hemprichii, but was substantial (about $54 \%$ of requirements) for $E$. acoroides at both sites (Table 3 ). $\mathrm{N}$ and $\mathrm{P}$ deficiency was greater in Lucero than in Silaqui (Table 3), in accordance with the differences in ambient nutrient concentration, which was higher in Silaqui. This difference in nutrient deficiency between sites was evident in $T$. hemprichii (i.e. plants in Lucero were twice as deficient as in Silaqui; Table 3). $\mathrm{N}$ and $\mathrm{P}$ relative deficiencies were close, so that nitrogen or phosphorus supplements would quickly drive the plants towards phosphorus or nitrogen limitation, respectively.

\section{DISCUSSION}

The results of the fertilization experiment provide conclusive evidence of nutrient-limited growth of seagrasses in Cape Bolinao. Leaf growth and biomass of Thalassia hemprichii and Enhalus acoroides increased significantly in response to nutrient additions at both 
Table 3. Estimated nutrient ( $\mathrm{N}$ and $\mathrm{P}$ ) requirements, nutrient incorporation rates, and nutrient deficiency for the species investigated at the 2 sites. Calculations are based on measurements of leaf nutrient concentrations and growth of fertilized and unfertilized (control) plants, as described in the text. Percent deficiency, shown in brackets, is calculated as the ratio between nutrient deficiency and requirements

\begin{tabular}{|c|c|c|c|c|c|c|c|}
\hline Species & Site & $\begin{array}{l}\text { N requirement } \\
\left(m g N \text { shoot }{ }^{-1} \mathrm{~d}^{-1}\right)\end{array}$ & $\begin{array}{l}\text { Prequirement } \\
\left(\mathrm{mg} \text { P shoot }{ }^{-1} \mathrm{~d}^{-1}\right)\end{array}$ & $\begin{array}{l}N \text { incorporation } \\
\left(m g N \text { shoot }{ }^{-1} d^{-1}\right)\end{array}$ & $\begin{array}{l}\text { P incorporation } \\
\left(\text { mg P shoot }{ }^{-1} \mathrm{~d}^{-1}\right)\end{array}$ & $\begin{array}{c}N \text { deficiency } \\
\left(m g N \text { shoot }^{-1} \mathrm{~d}^{-1}\right)\end{array}$ & $\begin{array}{c}\text { P deficiency } \\
\left(\mathrm{mg} \mathrm{Phoot}^{-1} \mathrm{~d}^{-1}\right)\end{array}$ \\
\hline $\begin{array}{l}\text { Thalassia } \\
\text { hemprichii }\end{array}$ & Silaqui & 0.0772 & 0.0069 & 0.064 & 0.0058 & $0.013(17 \%)$ & $0.0011(16 \%)$ \\
\hline $\begin{array}{l}\text { Thalassia } \\
\text { hemprichii }\end{array}$ & Lucero & 0.0904 & 0.0077 & 0.058 & 0.0050 & $0.032(36 \%)$ & $0.0027(36 \%)$ \\
\hline $\begin{array}{l}\text { Enhalus } \\
\text { acoroides }\end{array}$ & Silaqui & 0.3073 & 0.0782 & 0.143 & 0.0365 & $0.164(53 \%)$ & $0.0416(53 \%)$ \\
\hline $\begin{array}{l}\text { Enhalus } \\
\text { acoroides }\end{array}$ & Lucero & 0.3236 & 0.0489 & 0.149 & 0.0225 & $0.175(54 \%)$ & $0.0264(54 \%)$ \\
\hline
\end{tabular}

sites. Leaf biomass also increased in Cymodocea rotundata. In addition, nutrient additions caused a significant increase in the shoot density of $T$. hemprichii and C. rotundata. These results contrast with the lack of significant responses in the growth, shoot density and biomass of $T$. hemprichii and $E$. acoroides after a 4 to 5 mo fertilization experiment in plants growing over terrigenous and carbonate sediments in Indonesia (Erftemeijer et al. 1994). This disagreement may be largely methodological, since our study used a complete fertilizer added regularly over the 4 mo experimental period. At any rate, our results show that SE Asian seagrass communities may be nutrient limited.

Thalassia hemprichil responded to increased nutrient availability by increasing shoot density after a time lag of only approximately $2 \mathrm{mo}$, associated with a significant increase in the number of rhizome apical meristems (Agawin 1995). The observed increase in the number of dividing apical meristems of $T$. hemprichii in response to nutrient addition demonstrates that the activity of rhizome meristems was limited by nutrient deficiency, which results in the control of rhizome branching rate and, hence, shoot density and formation by nutrient availability.

Seagrasses have been reported to respond to nutrient deficiency by increasing biomass allocation to root development or belowground parts, thereby increasing the absorbing surface, at the expense of a decline in leaf growth and size (Pérez et al. 1991), as well as changes in root specific acquisition rate (Hemminga et al. 1994). This observation is supported here also, because the proportion of the biomass of Thalassia hemprichii allocated to belowground parts significantly declined in response to nutrient additions (Agawin 1995). This indicates a shift in resource allocation towards the production of leaf biomass, which increased significantly with increasing nutrient availability.
The increased seagrass growth with increasing nutrient availability was supported by the enhanced photosynthetic activity, which in turn was associated with higher chlorophyll and nutrient concentrations in the photosynthetic tissues. Nutrient additions generally led to increased maximum photosynthesis rate, lower respiration rates, increased photosynthetic efficiency, and lower light compensation points. These results indicate a link between nutrient deficiency and photosynthetic $C$ incorporation, which may result from the dependence of chlorophyll synthesis, as well as that of photosynthetic enzymes, on nutrient supply (Marschner 1986). The net effect of this link is a coupling between $\mathrm{C}$ incorporation and nutrient supply in the seagrasses studied. This response was, however, not evident in Enhalus acoroides, despite it also being nutrient limited, so that the coupling between photosynthetic rates and nutrient supply may be a speciesspecific feature. Even though the response of the photosynthetic activity of $E$. acoroides to nutrient enrichment was small, it did show the greatest response in growth and biomass, and the greater degree of nutrient deficiency.

The comparison among the responses of these 3 species shows, therefore, a gradation from species where increased biomass was coupled to a large improvement in photosynthetic performance (e.g. Cymodocea rotundata), to species where these 2 responses were uncoupled (Enhalus acoroides). This suggests that nutrient availability limited the growth of $C$. rotundata and Thalassia hemprichii through the limitation of their acquisition of $C$, while this link was weaker in $E$. acoroides. E. acoroides has bulky rhizomes $(13.2 \mathrm{~mm}$ in diameter, compared to $<4 \mathrm{~mm}$ for the other 2 species; Vermaat et al. 1995a), which may store a large C pool to supply carbon demands. Calculations of the rhizome carbohydrate pools available per unit leaf biomass indicate that E. acoroides rhizomes contain about $4.2 \mathrm{~g}$ of carbohydate per unit leaf biomass, compared to 2.5 
and $0.6 \mathrm{~g}$ for C. rotundata and T. hemprichii (Vermaat et al. 1995b). Hence, photosynthetic $C$ production is unlikely to limit the biomass of $E$. acoroides, when compared to the other 2 species. The severe nutrient limitation of $E$. acoroides may derive, instead, from the large losses of nutrients devoted to sexual reproduction. The biomass allocated to sexual reproduction of $E$. acoroides has been estimated, for the same sites studied here, to be at least comparable to that allocated to leaf and rhizome growth (Uri et al. unpubl.). The $\mathrm{N}$ and $\mathrm{P}$ contained within $E$. acoroides flowers and fruits $11.83 \% \mathrm{~N} \mathrm{DW}$ and $0.38 \% \mathrm{P} \mathrm{DW}$, and $1.3 \% \mathrm{~N} \mathrm{DW}$ and $0.14 \% \mathrm{P} \mathrm{DW}$, in this location respectively; Duarte unpubl. data) is lost from the plant, in contrast with the nutrients allocated to vegetative growth which can be reclaimed (Hemminga et al. 1991). Therefore, we suggest nutrient losses from sexual reproduction to be the likely cause for the nutrient limitation of $E$. acoroides, while that of $C$. rotundata and $T$. hemprichii appears to derive from nutrient-constrained photosynthetic carbon acquisition.

The nutrient concentrations in leaves of plants growing in control plots were all above the median values reported for seagrasses $(1.8 \% \mathrm{DW}$ for $\mathrm{N}$ and $0.2 \% \mathrm{DW}$ for P; Duarte 1990). This observation suggests that these median values, which have been suggested to be useful in predicting the likelihood of seagrass response to fertilizations (Duarte 1990), provide conservative estimates of critical nutrient levels for seagrasses. Alternatively, the nutrient concentrations reported, which were derived from analyzes of the second youngest leaf, may overestimate the average nutrient concentration of the leaf biomass, since the nutrient concentration of leaves decreases with increasing age (Pedersen \& Borum 1993).

We initially hypothesized that seagrasses in Lucero should be more nutrient limited than those in Silaqui. Responses to experimental nutrient additions were, however, mostly similar for Silaqui and Lucero, indicating a similar extent of nutrient limitation at both sites. The identity of the limiting nutrient was also similar for both sites, although it differed among species. Our results indicate phosphorus, and possibly $\mathrm{N}$, as primary limiting nutrients for Thalassia hemprichii, as reflected in the significant increase in its $\mathrm{P}$ concentration upon nutrient enrichment (Fig. 1). Nitrogen appears to be the primary limiting nutrient for Enhalus acoroides, as reflected in the significant increase in its $\mathrm{N}$ concentration in response to fertilization (Fig. 1). These observations indicate that the nutrient status of seagrasses species is also species-specific, for different species have contrasting nutrient status while growing at the same sites. The basis for these species-specific differences in the nature of the resources limiting to growth is unclear. We speculate that it may be related to differences in the way different species occupy the sediments. The bulk of $T$. hemprichii root biomass occurs 5 to $20 \mathrm{~cm}$ below the sediment surface, along with that of other species in the mixed meadow (e.g. Cymodocea rotundata, Cymodocea serrulata; Agawin unpubl. data). In contrast, the roots of E. acoroides are located much deeper $(>30 \mathrm{~cm}$ below the sediment surfacej than those of any other species in the mixed meadow, thereby avoiding interspecific root competition. This may allow for the very high phosphorus contents of its leaves compared to those of neighbouring $T$. hemprichii. The deep sediment layer occupied by $E$. acoroides may, however, be depleted in nitrogen, lost through mineralisation and denitrification after the original settlement of organic matter on the upper sediment layers. Hence, resource availability may shift vertically into the sediments, from phosphorus deficiency in the upper layers to nitrogen deficiency down below.

In summary, our results have demonstrated nutrient limitation of seagrass growth and photosynthetic performance at 2 contrasting sites at Cape Bolinao. The extent of responses, however, differed among sites and species. Differences among sites highlight the importance of local differences in the factors controlling nutrient losses and gains in seagrass meadows (cf. Hemminga et al. 1991). As a result, inferences on the occurrence and extent of nutrient limitation at the regional scale must be based on large-scale studies, rather than extrapolations from studies at a few locations, such as those available on the nutrient balance of SE Asian seagrasses (Erftemeijer 1993, Erftemeijer et al. 1994, Erftemeijer \& Middelburg 1995). Most importantly, our results indicate that the nature and extent of nutrient deficiency varies greatly among co-occurring species, indicating the possibility of simultaneous limitation of seagrass production by multiple nutrients in the mixed meadows that dominate in SE Asian coastal waters.

Acknowledgements. We thank J Vermaat for useful comments, L. McManus and G. Jacinto for valuable discussions, $D$. Lindenburg for analyzing plant $N$ and $P, G$. Jacinto and I. Velasquez for water nutrient analyses, H. Yap, R. Dizon and $R$. Montebon for assistance in the $P-I$ experiment, $P$. Rivera for access with his unpublished data, and J. Rengel for assistance in the field. This study was funded by The Engineering and Science Education Program (Department of Science and Technology] scholarship grant to N.S.R.A. and by the Project CI1 ${ }^{*}$-CT91-0952 of the European Community.

\section{LITERATURE CITED}

Agawin NSR (1995) In situ experimental evidence of nutrient limitation of seagrasses in Cape Bolinao. MS thesis, Unjversity of The Philippines 
Alcoverro T, Romero J, Duarte C, Lopez N (1995) Annual growth dynamics of Posidonia oceanica: contribution of large-scale versus local factors to seasonality. Mar Ecol Prog Ser 120:203-210

Balunos JH (1994) Growth response of three seagrass species to variations in sediment size. BS thesis, Pamantasan ng Lungsod ng Maynila

Bulthuis DA, Axelrad D, Mickelson MJ (1992) Growth of the seagrass Heterozostera tasmanica limited by nitrogen in Port Phillip Bay, Australia. Mar Ecol Prog Ser 89:269-275

Duarte CM (1990) Seagrass nutrient content. Mar Ecol Prog Ser 67:201-207

Duarte CM (1995) Submerged aquatic vegetation in relation to different nutrient regimes. Ophelia 41:87-112

Erftemeijer PLA (1993) Factors limiting growth and production of tropical seagrasses: nutrient dynamics in Indonesian seagrass beds. PhD thesis, Nijmegen Catholic University

Erftemeijer PLA, Middelburg J (1995) Mass balance constraints on nutrient cycling in tropical seagrass beds. Aquat Bot 50:21-36

Erftemeijer PLA, Stapel J, Smekens MJE, Drossaert WME (1994) The limited effect of in situ phosphorus and nitrogen additions to seagrass beds on carbonate and terrigenous sediments in South Sulawesi, Indonesia. J Exp Mar Biol Ecol 182:123-140

Giesen WBJT, van Katwijk MM, den Hartog C (1990) Eelgrass condition and turbidity in the Dutch Wadden Sea. Aquat Bot 37:71-85

Hemminga MA, Harrison PG, van Lent $F$ (1991) The balance of nutrient losses and gains in seagrass meadows. Mar Ecol Prog Ser 71:85-96

Hemminga MA, Koutstaal BP, van Soelen J, Merks AGA (1994) The nitrogen supply to intertidal eelgrass (Zostera marina). Mar Biol 118:223-227

Hillman K, Walker DI, Larkum AWD, McComb AJ (1989) Productivity and nutrient limitation. In: Larkum AWD, McComb AJ, Shepherd SA (eds) Biology of seagrasses. A treatise on the biology of seagrasses with special reference to the Australian region. Aquatic Plant Studies 2, Elsevier Science Publishers, Amsterdam, p 635-685

Marschner H (1986) Mineral nutrition of higher plants. Academic Press, London

McRoy CP (1974) Seagrass productivity: carbon uptake experiments in eelgrass, Zostera marina. Aquaculture 4: $131-137$

Montebon AR, Yap HT (1995a) Metabolic responses of the scleractinian coral Porites cylindrica Dana to water motion. I. Oxygen flux studies. J Exp Mar Biol Ecol $186: 33-52$

This article was submitted to the editor
Montebon AR, Yap HT (1995b) A device to enable multireplicate measurements in dissolved oxygen respirometry. Coral Reefs 14:54

Murray L, Dennison W, Kemp M (1992) Nitrogen versus phosphorus limitation for growth of an estuarine population of eelgrass (Zostera marina L.). Aquat Bot 44: $83-100$

Orth RJ (1977) Effect of nutrient enrichment on growth of the eelgrass Zostera marina in the Chesapeake Bay, Virginia, U.S.A. Mar Biol 44:187-194

Pedersen M, Borum J (1993) An annual nitrogen budget for a seagrass Zostera marina population. Mar Ecol Prog Ser 101:169-177

Pérez M, Romero J, Duarte CM, Sand-Jensen K (1991) Phosphorus limitation of Cymodocea nodosa growth. Mar Biol 109:129-133

Potvin C, Lechowicz MJ, Tardif S (1990) The statistical analysis of ecophysiological response curves obtained from experiments involving repeated measures. Ecology 71: $1389-1400$

Powell G, Kenworthy J, Fourqurean J (1989) Experimental evidence for nutrient limitation of seagrass growth in a tropical estuary with restricted circulation. Bull Mar Sci 44:324-340

Short FT, Dennison WC, Capone DG (1990) Phosphoruslimited growth of the tropical seagrass Syringodium filiforme in carbonate sediments. Mar Ecol Prog Ser 62: $169-174$

Sokal RR, Rohlf FJ (1981) Biometry. The principles and practice of statistics in biological research, 2 nd edn. WH Freeman and Co, New York

Strickland JDH, Parsons TR (1972) A practical handbook of seawater analysis, 2nd edn. Bull Fish Res Bd Can 167: $1-310$

Vermaat JE, Agawin NSR, Duarte CM, Fortes MD, Marbà N, Uri JS (1995a) Meadow maintenance, growth and productivity of a mixed Philippine seagrass bed. Mar Ecol Prog Ser 124:215-225

Vermaat JE, Duarte CM, Fortes MD, Agawin NSR, Marbà N, Uri JS (1995b) Final report for the latitudinal variation in life history patterns and survival mechanisms in selected seagrass species as a basis for ElA in coastal marine ecosystems. EC DG XII-G International Scientific Cooperation Project, IHE, Delft

Wintermans JFGM, De Mots A (1965) Spectrophotometric characteristics of chlorophylls $a$ and $b$ and their pheophytins in ethanol. Biochim Biophys Acta 109:448-453

Zieman JC (1974) Methods for the study of the growth and production of turtle grass, Thalassia testudinum König. Aquaculture $4: 139-143$

Manuscript first received: November 28, 1995

Revised version accepted: March 13, 1996 